\title{
Lenin on library organisation in socialist society
}

\author{
Joe Pateman
}

Department of Politics, The University of Nottingham, Nottingham, United Kingdom

Journal: Library and Information History, accepted on the 19/04/2019.

Email: joepateman@yahoo.co.uk Tel.no.07545 386897

Biographical note: Joe Pateman is a PhD candidate currently studying at the University of Nottingham, with a specific interest in the disciplines of Marxism-Leninism, democratic theory, and political economy. Joe's Mres thesis studied the relationship between Lenin's conception of scientific socialism and democracy, whilst his $\mathrm{PhD}$ thesis explores Lenin's theory of democracy. His recent publications include a co-authored article and book, 'Managing Cultural Change in Public libraries: Marx, Maslow and Management' (2019). His interest is in how libraries can provide a democratic public space in an increasingly commercialised world. He is a member of the editorial board for Information for Social Change.

Funding details: This article was self-funded.

Disclosure statement No financial interest or benefit has arisen from the direct applications of this research. There is no conflict of interest/nothing to disclose 


\title{
Lenin on library organisation in socialist society
}

\begin{abstract}
Vladimir Ilyich Lenin, founder of the Communist Party of the Soviet Union and leader of the first Socialist State in the world, devoted great attention from the very first days of the soviet power to the education of the people, to organising the work of cultural and educational institutions, libraries and reading rooms. He considered libraries as the most massive and accessible centres of political education for the workers, propagation of knowledge, and the raising of the peoples cultural and technical level. Lenin's works, reports and speeches, notes and draft resolutions of Party and state organisations contained a detailed programme for constructing the Soviet socialist system of library services for the people.
\end{abstract}

Keywords: Lenin, Libraries, class, culture, working class, middle class

\section{Introduction}

When one reads over Lenin's statements on library matters one feels how important and vital they are. Library matters were very near to his heart

- N. K. Krupskaya. ${ }^{1}$

The $100^{\text {th }}$ year anniversary of the Bolshevik Revolution revitalised western academic interest in the life and ideas of V. I. Lenin, the founder of the Communist Party of the Soviet Union and leader of the world's first socialist state. Several studies brought new aspects of his thought and practice to light, whilst simultaneously questioning some of the widely accepted narratives established by the (mostly) hostile Cold War 'Leninologists'. In particular, more commentators are now rejecting the long-standing myth that Lenin had few interests outside the sphere of revolutionary Marxist politics. He did, not, as Polan contends, live, think and act solely within this 'microscopic universe'. ${ }^{2}$ According to Tariq Ali, for instance, Lenin's writings showcase a passion not only for Marxism, politics and revolution, but classical Russian literature as well. ${ }^{3}$

In spite of this recent 'renaissance', however, most commentaries still focus upon Lenin's work in the political sphere, and comparatively little has been written about his ideas on culture and education. This article outlines Lenin's contributions in these areas by analysing his writings on the soviet socialist library service. ${ }^{4}$ Lenin argued that the library should serve the goals of socialism, by educating the working class masses, raising their cultural 
level, and fulfilling their needs. This article concludes by highlighting the continuing relevance and significance of his ideas for librarianship today. ${ }^{5}$

\section{Lenin on library organisation in socialist society}

According to Lenin, the Great October Socialist Revolution began a new stage in the development of public librarianship by creating the objective conditions for free access to books, knowledge and information on behalf of the working class. Under these new economic and political conditions, it became both possible and necessary to transform the tasks of the public library:

In the old days, human genius, the brain of man, created only to give some the benefits of technology and culture, and to deprive others of the bare necessities, education and development. From now on all the marvels of science and the gains of culture belong to the nation as a whole, and never again will man's brain and human genius be used for oppression and exploitation. Of this we are sure, so shall we not dedicate ourselves and work with abandon to fulfil this greatest of all historical tasks? The working people will perform this titanic historical feat, for in them lie dormant the great forces of revolution, renascence and renovation. ${ }^{6}$

In the weeks and months following the socialist revolution, Lenin noticed that the change in economic and political conditions had brought about a corresponding shift in the attitude of the masses: They had developed an even stronger desire to read, educate themselves, and develop the new, socialist culture. The workers expressed this desire by demanding the construction of new public libraries, as well as the improvement of the existing ones. In his observation of these developments, Lenin noted that ' $[t]$ he thirst for knowledge among the mass of workers and peasants is tremendous... the striving for education and the establishment of libraries is mighty and "popular" in the real sense of the word'. The revolution had created both the objective and subjective conditions for the development of libraries. ${ }^{7}$

Whilst the socialist transformation had bought about 'the political and social revolution', Lenin did not think that this guaranteed a successful transition to communism. As he explained in one of his works, the masses could develop the necessary political consciousness and strengthen their commitment to the socialist cause only if they had access to the relevant reading material. It was all well and good having a literate population, but if there was nothing to read, then there could be no hope of advancing to socialism. Accordingly, a 'cultural revolution' was also necessary 'to make [Russia] a completely socialist country':

...it is not enough to abolish illiteracy, it is necessary to build up Soviet economy, and for that literacy alone will not carry us very far. We must raise culture to a much higher level. A man must make use of his ability to read and write; he must have something to read, he must have newspapers and propaganda pamphlets, which should be properly distributed and reach the people... we must...ceaselessly propagate the idea that political education calls for raising the level of culture at all 
costs. The ability to read and write must be made to serve the purpose of raising the cultural level; the peasants must be able to use the ability to read and write for the improvement of their farms and their state. ${ }^{8}$

All the major figures involved in the tasks of library construction in the Soviet Union argue that Lenin devoted great attention from the very first days of the soviet power to the education of the people, to organising the work of cultural and educational institutions, libraries and reading rooms. They point out that he considered libraries as the most massive and accessible centres of political education for the workers, propagation of knowledge, and the raising of the peoples cultural and technical level. ${ }^{9}$ More generally, he viewed them as an index to cultural level of the country. ${ }^{10}$

Lenin's works, reports and speeches, notes and draft resolutions of Party and state organisations contained a detailed programme for constructing the Soviet socialist system of library services for the people. These documents provided theoretical and practical guidance for almost every area of their organisation and development. In What can be done for Public Education, Lenin's Marxist analysis of pre-revolutionary Russia identified 'regulations, discussed and elaborated by a dozen committees of civil servants inventing hundreds of formalities and obstacles to the use of books'. In addition, the 'huge public libraries containing hundreds of thousands and millions of volumes' were 'reserved' only for a 'guild of scholars, professors and other such specialists'. Under socialism, Lenin argued that this had to change. $\mathrm{He}$ rejected the belief that it was still necessary to 'protect' the 'public libraries from the mob, from the hoi polloi!'. 'These gigantic, boundless libraries' had to be made 'available to the masses, to the crowd, to the mob!'. The soviet power had to 'see to it that even children can make use of the rich collections; that readers can read publicly- owned books at home'. 'All the libraries in Russia' had to be amalgamated so that 'there would be enough books to satisfy those who can read... [and] teach those who cannot'. There had to be a 'real integrated network of libraries'. ${ }^{12}$

In Lenin's opinion, the most important condition for creating this system was the principle of Party and state guidance in cultural and library construction, the leading and directing role of the Communist Party and the soviet government in creating an extensive network of libraries and the requisite materials and financial basis for organising public use of the library book stocks. As he emphasised long before the socialist revolution:

Publishing and distributing centres, bookshops and reading-rooms, libraries and similar establishments - must all be under party control. The organised socialist proletariat must keep an eye on all this work, supervise it in its entirety, and, from beginning to end, without any exception, infuse into it the life-stream of the living proletarian cause. $^{13}$

Lenin argued that the libraries had to be subordinate to the workers vanguard, i.e. the Communist Party, which could monitor, guide, and even redirect its activities if necessary. Because the Party was composed of the most advanced, determined, and politically conscious, elements of the working class, it could ensure that the public libraries carried out their tasks. 
In his draft for the Party programme Lenin wrote that the 'organisation of libraries' and reading rooms was crucial in providing '[a]ll-round help on the part of Soviet power in the matter of the self-education and selfdevelopment of workers and working peasants', and for also aiding the other educational and enlightenment institutions. ${ }^{14}$ Direct leadership in developing a system of mass and scientific libraries was exercised by The People's Commissariat for Education, within which were created: the Scientific Libraries Department, the Library Section of the led the Extra-Mural Department, and others. ${ }^{15}$

Lenin's teaching on the leading and guiding role of the Communist Party and the Soviet State in socialist construction and library organisation, his statements on the class character of library work, on the subordination of library work to the building of the new, socialist society, determined in principle the social role and significance of libraries and shaped their new social functions. Already during the pre-revolutionary period in Russia, Lenin put forward and grounded the principle of partisanship in libraries, of their active participation in carrying out socialist transformations. ${ }^{16}$ For instance, in the period of reaction which set in after the defeat of the first Russian revolution of 1905-07, the R.S.D.F.P(B.) was forced underground, but it did not cease its struggle against the autocracy. In those years Lenin repeatedly insisted that it was 'essential for the maximum possible initiative to be shown in the organisation of S.D. work in legally existing associations' including the 'reading rooms [and] libraries', primarily for the dissemination of party literature and Marxism. ${ }^{17}$ During this period Lenin also criticised the bourgeois assertions of the non-political, non-party character of library work in a class society. ${ }^{18}$ In the first place, he denounced the educational policy of the Russian ruling classes in relation to the masses, which was to create cheap libraries that published anti-socialist, pro monarchist literature, with the aim of fighting the revolutionary movement:

Whenever you see a signboard: "People's Library"-you can afford to exult. There you will find cheap or even free pamphlets issued by the Union of the Russian People or the All-Russia Nationalist Club, under the medical supervision of the spiritual censorship. ${ }^{19}$

In another article on the Organisation of the Masses by the German Catholics, Lenin argued that The People's Union for a Catholic Germany also used libraries as a tool to gain support for their reactionary cause:

Work at the party executive is organised on strictly factory lines. Twenty special officials are in charge of 'literature': one handles theology, another, the agrarian question, a third, the social-democratic movement, a fourth, the artisans. Etc. They make cuttings and extracts from newspapers and journals, and keep a card index. They have a staff of stenographers. A Special library has 40,000 volumes. $^{20}$

After the victory of the October Revolution Lenin repeatedly stressed the indissoluble link of library organisation with the policy of the party and the government and with the tasks of building socialism and communism. ${ }^{21}$ 
Lenin realised that the masses required a high level of technical and scientific knowledge in order to effectively manage the various spheres of socialist society, and they could acquire this knowledge only if they had access to the relevant reading material. As he put it, 'It takes knowledge to participate in the revolution with intelligence, purpose and success'. ${ }^{22}$ As such, Lenin drew attention to the importance of the libraries' contribution to drawing the people into fulfilling state plans for socialist transformation. $\mathrm{He}$ stressed their obligation to promote scientific and technical progress, the spreading of scientific and technical information, as well as the dissemination of propaganda of advanced production experience amongst the working masses. $^{23}$

Even when Russia was in a 'state of poverty' immediately following the revolution, Lenin insisted that it was still imperative to 'give the people...through each of the 50,000 libraries and reading rooms', the widest range of educational material. Firstly, every library had to supply multiple copies of the state owned daily newspaper, for '[e]ach of these could carry to the people every day serious and valuable literary material and the best modern and classical fiction'. Secondly, Lenin insisted that the public libraries had to offer 'all the necessary textbooks' 'on general subjects', 'world classics...books on modern science and engineering', 'agriculture and industry'. ${ }^{24}$ The 'classics' included, above all else, 'everything published by Marx and Engels'. ${ }^{25}$ Once a new book had been published domestically, Lenin was adamant that the public libraries should have it in stock as soon as possible. He stressed the importance of this in a letter to Y. A. Litkens, in which he wrote that: 'you (and we) must be absolutely sure whom we are to jail...from...the library network... if within one month (2 weeks? 6 weeks?) after the publication of every Soviet book it is not available at every library'. ${ }^{26}$ Third, after the foreign military intervention and civil war, during the period of rehabilitation of the national economy, Lenin worked systematically to improve the stocks of libraries, their provision with pamphlets on production, accounts and reports of economic and management institutions, scientific and technical publications. ${ }^{27} \mathrm{He}$ hoped that by bringing these documents 'within reach of the broad masses of the population, by supplying copies to every library', this would 'enlist far greater numbers in the economic drive'. ${ }^{28}$ Noting the importance of spreading through 'all libraries in the R.S.F.S.R' scientific and technical literature, 'pamphlets and leaflets dealing with questions of production', and accounts of economic institutions and conferences, Lenin wrote on April 11, 1922 that 'unless an increasing number of the population grow accustomed to reading these reports in the libraries, it is useless talking about transforming this semi-barbarous country into a cultured and socialistic one'. ${ }^{29}$

Lenin also rejected the idea that the libraries should restrict the kinds of books they housed. In particular, he opposed the notion that they should only provide those that were pro socialist. Lenin maintained this position even when counterrevolutionary bourgeois forces besieged and threatened the soviet state. In 1920, for instance, during the height of the brutal civil war between the communist reds and the reactionary whites, Lenin issued a 'Resolution of the Council of People's Commissars', which demanded that the various state organs 'send all the whiteguard literature, Russian and foreign, in 
their possession...to the People's commissariat for Education for safekeeping and public use in state libraries'. ${ }^{30}$

Lenin's statements on the social character of libraries determined the qualitatively new content of their activity directed at accustoming the broad masses to reading, at creating the necessary conveniences in libraries, at making libraries accessible to the general public, and democratising the forms and methods of library service: As he put it in an article he wrote before the revolution, librarians should:

...regard as the pride and glory of a public library, not the number of rarities it contains, the number of sixteenth-century editions or tenthcentury manuscripts, but the extent to which books are distributed among the people, the number of new readers enrolled, the speed with which the demand for any book is met, the number of books issued to be read at home, the number of children attracted to reading and to the use of the library... ${ }^{31}$

Lenin emphasised the importance of home reading in particular. Because 'only a few people can visit the library...the rational organisation of educational work [should be] measured by the number of books issued to be read at home, by the conveniences available to the majority of the population'. ${ }^{32}$ In his view, a public library that operates according to these criteria is bound to attract ever-larger sections of the masses and satisfy their needs.

Lenin also suggested that every library should contain a 'special, central, reading-room for children', and it was imperative that 'the librarians do everything for the children's convenience and answer their questions'. ${ }^{33}$ The public libraries had to employ workers who were friendly and approachable to the masses, and who served their requests. If a librarian avoided the patrons, whether due to personal inclination or prejudice, they were failing at their job. In particular, the librarians who looked down their noses at the working class patrons and their children had to be removed from their posts.

At Lenin's behest, the Council of People's Commissar's charged the library department of the People's Commissariat for Education with providing factual data on the 'actual increase in the number of libraries and reading rooms and in the present spread of books among the population'. It was also imperative, in his view, to 'increas[e] the establishments and number of librarians of the public government state libraries'. ${ }^{34}$ Lenin thought that the socialist library service could maximise its influence 'if the "travelling libraries" "were 'properly organised', for these could reach the remote areas of Russia that lacked even the most basic educational provisions. ${ }^{35}$ In the longterm, it was necessary to 'have a branch of the Public Library... within ten minutes walk of the house of every inhabitant' with 'the branch library being the centre of all kinds of institutions and establishments for public education'. Each of the library branches had to provide not only for 'the use of reference books in the building and the issue of books to be read at home'. They also had to provide 'a place for evening lectures, for public meetings and for rational entertainment'. ${ }^{36}$ Lenin's conscious aim was to gradually transform the public library into a social hub for the masses, and a kind of second home for the working class. It was to function not only as a place to read in silence, 
but also as a place to house 'all kinds' of social and educational activities. It had to provide a space where the workingmen and women could meet together, talk, discuss, and organise their affairs. In his view, the best public libraries were the ones that facilitated the activities that the workers themselves demanded.

Lenin's demands for promoting reading among the working masses, 'training the population sufficiently to acquire the habit of book-reading', the constant concern of the state 'that there should be people to read, that the number of people able to read is greater'-these instructions influenced in principle the formation of the soviet system of library services for the working people and of soviet library science as a social science. ${ }^{37}$ Organisation of reading by the whole people, bringing the book stocks within reach of all, became a distinctive feature of the soviet library as a library of a new, socialist type. Guided by Lenin's instructions, soviet library science bought into the foreground the problems of the ideological content of reading, it considered library work as an active, purposeful process, and it viewed in the library a powerful instrument for communist education and for raising the cultural and technical level of the working people.

Lenin maintained that the socialist public libraries should never rest on their laurels and decide that they were doing the best possible job of serving the working masses. They should never believe that they were optimising the proletariat's self-education and self-actualisation. In his view, they could always do a better job at this, and as such, he argued that they had to constantly strive to improve their services. One of the key ways of ensuring this was the encouragement of inter-library competition:

More than anything else the libraries, including of course reading huts, all kinds of reading rooms, etc., require competition between individual provincial libraries, groups, reading rooms, etc. The proper way to send in accounts, which is now demanded by the Council of People's Commissars, should serve three aims:

1) authentic and complete information to the Soviet government and all citizens about what is going on;

2) enlisting the public in library work;

3) encouraging competition among library workers. ${ }^{38}$

The 'three aims' outlined above deserve further attention. The first point expresses Lenin's belief that the public libraries had to be transparent in all of their activities. They had to let the Party, state and masses know what they were doing with regards to any proposed changes that they had planned. Because the government and masses had access to every aspect of their organisation, the libraries were incentivised to perform efficiently and fulfil their intended function. This measure also ensured that the libraries remained accountable to the people. If the Party, government or masses did not like an aspect of the library's work, or if they disproved of a particular change, then they could exercise their power of control and instruct the library to remedy the problem.

The second aim, of 'enlisting the public in library work', was a key component of Lenin's conception of socialist democracy, which sought to maximise the participation of the broadest masses in the administration of 
society; and thereby gradually abolish the distinction between the rulers and the governed. In its application to public libraries, this aim demanded that the workers directly and indirectly participate in the management, organisation and development of the libraries. As more workers got involved over time, this would diminish the division of labour between the library staff and the masses. More generally, this development would contribute to a long-term goal of socialist democracy- the withering away of the state and the transition to communism.

The third aim, of encouraging comradely competition amongst library workers, strived to create the best possible service for the masses. By competing against each other in every aspect of library organisation and service delivery, the staff would try to execute their tasks in the most effective way. This would not only reduce the possibility of the workers becoming lazy, complacent, or un-comradely in their attitudes towards the masses. It also safeguarded against any potential attempts to undermine or sabotage the fundamental aims of the public library.

In addition to the aims outlined above, Lenin suggested that public libraries could objectively assess their performance by measuring the fulfilment of the following criteria:

For example: 1) Can you supply precise information to prove more books have been lent from your library? or 2) how many people visit your reading room? 3) book and newspaper exchange with other libraries and reading rooms? or 4) compilation of a central catalogue? or 5) work on Sundays? or 6) work in the evenings? or 7) encouragement of new readers, women, children, non-Russians, etc.? or 8) satisfaction of readers' references? or 9) simple and practical means of storing books and newspapers? Saving them? Mechanical means of obtaining the book and returning it to its place? or 10) lending a book? Or 11) simplification of guarantees in lending a book? Or 12) sending it through the post? And so on, ad infinitum...

In order to provide an extra incentive, Lenin argued that the state should also 'reward (by giving bonuses in the form of valuable books, collections, and so on) those who make the most improvements and carry them out best of all'. ${ }^{40}$

As leader of the soviet government Lenin showed great concern for reorganising the library service for the population. The plan he worked out envisaged reorganising the distribution and use of book stocks and planned organisation of the whole library system in the interests of the working people. On the basis of his detailed knowledge of the state of library organisation in Russia and other countries, and of the main tendencies of its development, Lenin formulated the principles of a socialist system of library service for the people. ${ }^{41}$ As he put it in one of his works:

...this system must work according to a definite plan, determine the basic types of libraries, link them by means of mobile libraries, organise exchange of books between libraries and thus bring books closer to the worker and peasant reader. ${ }^{42}$ 
On Lenin's initiative the soviet government adopted several resolutions and decrees aimed at radically reorganising library practice on socialist principles. $^{43}$ Lenin attached great significance to centralising library administration and uniting all libraries in a united nation-wide system, to liquidating parallelism, duplication and departmental disunion in library organisation:

We must utilise the books that are available and set to work to organise a network of libraries which will help the people to gain access to every available book; there must be no parallel organisations, but a single, uniform planned organisation. This small matter reflects one of the fundamental tasks of our revolution. ${ }^{44}$

Lenin insisted on the conscious and purposeful management of the process of organising the soviet library system on the basis of a scientifically evolved state plan foreseeing the rational distribution of libraries throughout the country, as well as their concerted and interconnected functioning on principles of coordination and cooperation. Only then could libraries contribute actively to getting the working people quickly into the habit of reading.

Lenin's plan for organising libraries was given the force of law by the decree 'On Centralisation of Library Organisation in the R. S. F. S. R', which foresaw: the creation of a unified system of libraries including all types and kinds of libraries for the general public, regardless of which department they belonged to; the establishment of a single state centre to direct library organisation (the Central Interdepartmental Library Commission charged with redistributing book stocks and regulation aimed at eradicating disunion in library organisation); centralisation of books supplies for all libraries though a system of central and local library distributors. ${ }^{45}$ These ideas of Lenin were radically new in world practice and were dictated by the entire character of the October revolution, which introduced the principle of planning and organisation into library work.

The eradication of private libraries and book stocks formed a major part of the centralising process. Given the general shortage of books in the country, Lenin saw little justification in maintaining private collections. In his view it was obvious that if as many people were to have access to the books, they needed to be concentrated in the public libraries:

We must see to it that books and newspapers are, as a rule, distributed gratis only to the libraries and reading-rooms, which provide a proper reading service for the whole country and the whole mass of workers, soldiers and peasants. This will accelerate, intensify and make more effective the people's eager quest for knowledge. ${ }^{46}$

Whilst Lenin recognised that 'private' book collections made sense in capitalist society, where the bourgeois classes worshipped at the shrine of private property, he argued that they were incompatible with the economic basis and communitarian ethic of socialism. Under the new economic and political conditions, it was more beneficial to share educational resources amongst the entire community. Thus, In his 1920 'Decree of the Council of 
People's Commissars on the nationalisation of stocks of books and other printed matter', Lenin declared that private libraries and privately owned books were now state-owned. The aim of this measure was to provide more books for the public libraries:

All stocks of books and other printed matter...belonging to private individuals and to cooperative and other institutions and also those municipalised by the soviets are declared state property (are nationalised)... Owners of books and co-operative organisations guilty of concealing stocks of books and other printed matter will be prosecuted. $^{47}$

Lenin wanted the transition from private book ownership to public ownership to go peacefully and voluntarily, if possible. He asked the 'former owners' of 'all former private libraries'- the ex bourgeoisie and affluent members of society- to 'hand over all books presenting a great historical, scientific, or literary interest and concentrate them [in] special pub[lic] book depositories'. ${ }^{48}$ If these ex owners were not forthcoming, however, then Lenin encouraged the soviet state to seize their private book collections, so that the masses could access them in the public libraries. It was necessary, he argued, for the government to 'requisition and place at the use and disposal of the corresponding educational establishments all libraries...including all libraries of former estate owners'. ${ }^{49}$ For example, on December 27, 1918, an extraordinary commission of the town of Rodinki decided to requisition the private library of P. I. Surkov, a former member of the Social-Democratic group in the Third Duma. Its decision noted that "the books in Citizen Surkov's library, which are of social value, are shut away and unread at a time when there is an immense lack of books for the enlightenment of broad masses of workers and peasants", and that since a library was being formed in Rodniki "the requisitioned books will be of tremendous benefit as public property". ${ }^{50}$ In order to give Lenin fuller information on this question, the meeting decided to send A. N. Prokofiev, secretary of the local Cheka, to see him. Lenin received Prokofiev, and after a talk with him, wrote the following letter to the People's Commissariat for Education. Lenin's position on the issue was unambiguous:

[The] request for the requisitioning of Surkov's library for a district of 40,000 people is, in my opinion, correct...help the Rodniki comrades to expand their library. Can they not be sent one of the libraries requisitioned from the landowners?. ${ }^{51}$

In keeping with his dialectical conception of social development, Lenin argued that socialist public libraries should maintain and develop the positive characteristics of their capitalist counterparts, whilst discarding their flaws. In particular, he repeatedly called for the 'introduction of the Swiss-American system', the features of which included: quick service, free access to bookshelves, inter-library loan, general catalogues, and others. ${ }^{52}$ He made this task explicit in his article on the Tasks of the Public Library in Petrograd, which he wrote one month after the Socialist Revolution: 
The following changes, based on principles long practised in the free countries of the West, especially Switzerland and the United States, must be made immediately and unconditionally:

(1) The public library (the former Imperial Library) must immediately start an exchange of books with all public and state libraries in Petrograd and the provinces and with foreign libraries (in Finland, Sweden, etc.).

(2) The forwarding of books from one library to another must be made post-free by law.

(3) The library's reading-room must be open, as is the practice with private libraries and reading-rooms for the rich in civilised countries, from 8.00 a.m. to 11.00 p.m. daily, not excluding Sundays and holidays. ${ }^{53}$

On the one hand, therefore, Lenin argued that the socialist public library service should carry forward the progressive 'principles' of the libraries under capitalism. On the other hand, however, he also thought that it signified a higher, more advanced stage of development.

In conclusion, whilst Lenin may have been a devoted Marxist revolutionary, he also recognised the educational power, cultural significance and radical potential of libraries. Two aspects of his thought are particularly relevant for the theory and practice of libraries today. Firstly, Lenin convincingly rejects the myth that libraries are 'classless', in the sense that they provide their services equally to everyone. His core message is that the library always had, and always will have, a specific class character. Secondly, Lenin rejects the equally mistaken notion that libraries should function purely as a non-sociable place for 'individuals' to read books in isolation and silence. He rightly recognises that they can and should do much more than this. Aside from providing information and knowledge, libraries should also create a welcoming space for those with the most needs- the labouring masses- to socialise, discuss and enrich their culture. By doing this, libraries can provide the material resources to facilitate the self-education, self-emancipation, and self-governance of the working class.

\footnotetext{
${ }^{1}$ N. K. Krupskaya, "Forward to the first edition of "What Lenin wrote and said about libraries", in Lenin, Krupskaya and Libraries, ed. by S. Simova (London: Clive Bingley Ltd, 1968), p. 9.

${ }^{2}$ A. J. Polan, Lenin and the End of Politics (London: Meuthen, 1984), p. 135.

${ }^{3}$ T. Ali, The Dilemmas of Lenin: Terrorism, War, Empire, Love, Revolution. (London: Verso, 2017).

${ }^{4}$ The most complete collection of Lenin's writings on libraries is contained in the thematic collection V. I. Lenin and Library Organisation, which was published in Russian by Kniga Publishers. This collection, which runs to a hefty 431 pages, contains some 300 works, documents and other material. See V. I. Lenin, V. I. Lenin and Library Organisation (Moscow: Kniga publishers, 1977), $2^{\text {nd }}$ ed. (revised and enlarged, in Russian). In 1983 Progress Publishers released an abridged English language edition. See V. I. Lenin, Lenin and Library Organisation (Moscow: Progress Publishers, 1983). As for western
} 
English language collections, Simsova's anthology documents Lenin's concern for the establishment of public libraries in soviet Russia. See V. I. Lenin, 'Lenin on Libraries', in Lenin, Krupskaya, and Public Libraries, ed. By S. Simsova (London: Clive Bingley Ltd, 1968), pp. 9-43. Several other publications also acknowledge Lenin's influence upon soviet librarianship. See P. L. Horecky, Libraries and Bibliographical Centres in the USSR (Bloomington: University of Indiana, 1959), pp. 1, 76; E. Dudley, Introduction to Lenin, Krupskaya and Libraries, ed. by S. Simova (London: Clive Bingley Ltd, 1968), p.7; K. I. Abramov and V. V. Skvortsov, 'The library's social role: a soviet view', in Libraries in Society, ed. by D. Gerard (London: Clive Bingley, 1978), pp. 151-55; E. Kasinec, 'Libraries in the Soviet Union', Socialism and Democracy, 5 (1989), 175; A. Rubinstein, 'Lenin on literature, language and censorship', Science \& Society, 59 (1995), 368.

${ }^{5}$ For an analysis of Lenin's view of western capitalist libraries, see J. P. Pateman and J. Pateman, Managing Cultural Change in Public Libraries: Marx, Maslow and Management (London: Routledge, 2019), pp. 81-84.

${ }^{6}$ V. I. Lenin, Collected Works, in 45 volumes (Moscow: Progress Publishers, 1974), vol. 26, pp. 481-82.

${ }^{7}$ Collected Works, vol. 32, p. 128

${ }^{8}$ Collected Works, vol. 33, pp. 475, 74-75

${ }^{9}$ Krupskaya, p. 9-10; A. V. Lunacharsky, 'Books to all parts of Russia', in Lenin and Library Organisation, ed. by K. I. Abramov, (Moscow: Progress Publishers 1983), p. 176; 'Reminisces of the October Revolution', in Lenin and Library Organisation, pp. 177-78; M. N. Pokrovsky, 'Opening speech at the first library conference of the R.S.F.S.R', in Lenin and Library Organisation, pp. 179-80; V. D. Bonsch-Brueyevich, 'On the history of the organisation of the Russian central book chamber in Moscow', in Lenin and Library Organisation, pp. 182, 186.

${ }^{10}$ Later Leninists made this point the foundation of their own theories on the role of public libraries. For example, Enver Hoxha, the leader of the People's Socialist Republic of Albania, wrote that 'the development of the activity of libraries indicates the rise of the cultural level of the people'. See E. Hoxha, Selected Works, vol. 2 (Tirana: 8 Nentori Press, 1975), p. 46.

${ }^{11}$ Collected Works, vol. 19, p. 277.

${ }_{12}$ Collected Works, vol. 29, p. 337; vol. 21, p. 128.

${ }^{13}$ Collected Works, vol. 10, p. 46.

${ }^{14}$ Collected Works, vol. 29, p. 112.

${ }_{15}$ Collected Works, vol. 44, p. 180.

${ }^{16}$ Collected Works, vol. 10, p. 44; vol. 17, pp. 472-74.

${ }^{17}$ Collected Works, vol. 17, p. 473.

${ }_{18}^{18}$ Collected Works, vol. 36, pp. 244-46; vol. 20, pp. 259-61.

19 Collected Works, vol. 41, p. 29. The union of the Russian people was an extremely reactionary monarchist organisation that appeared in Russia in 1905 with the aim of fighting the revolutionary movement.

${ }^{20}$ Collected Works, vol. 36, p. 245.

${ }^{21}$ Collected Works, vol. 28, pp. 437-38; vol. 29, pp. 111-12.

${ }^{22}$ Collected Works, vol. 26, p. 352.

${ }^{23}$ Collected Works, vol. 31, pp. 404-06; vol. 33, pp. 74-75, 78-79. 
${ }^{24}$ Lenin argued that it was important for the special libraries in particular to have the most up to date educational materials. In a 1921 letter To the Foreign Literature Committee (Fortlicom) he demanded the following: 'The main task that Forlitcom should set itself is to have the special libraries in Moscow, Petrograd and the major cities of the Republic concentrate in their hands one copy each of all the latest technical and scientific (chemistry, physics, electrical engineering, medicine, statistics, economics, etc.) magazines and books for 1914-1921 published abroad, and to have regular receipt of all periodicals arranged. I shall appraise the whole of Forlitcom's work primarily from the standpoint of the actual fulfilment of this assignment'. See Collected Works, vol. 45, p. 318.

${ }^{25}$ Collected Works, vol. 32, p. 132; vol. 45, pp. 80-81.

${ }^{26}$ Collected Works, vol. 45, p. 145.

${ }^{27}$ Ibid., vol. 45, pp. 117, 360, 393-94; vol. 42, pp. 303-04; Lenin and Library Organisation, pp. 73-74.

${ }^{28}$ Collected Works, vol. 32, p. 439-40.

29 Collected Works, vol. 31, p. 406; vol. 33, p. 339. In the same work Lenin argues that 'Materials published in the newspaper or addressed to it [i.e. production- J. P.], as well as all other kinds of material, should be systematically and periodically brought out in pamphlet or leaflet form and compulsorily supplied to libraries'. See Collected Works, vol. 31, p. 406.

${ }^{30}$ Lenin on Library Organisation, pp. 54, 55

${ }^{31}$ Collected Works, vol. 19, p. 277.

32 Ibid., p. 278.

${ }^{33}$ Collected Works, vol. 19, pp. 278-79.

${ }^{34}$ Lenin on Library Organisation, pp. 138, 53

${ }^{35}$ Lenin decided to support the 'travelling libraries' after reading F. Dobler's article, the 'Modern Library Network', which was published in Pravda No. 24, February 4, 1921. He remarked that 'in my opinion, Comrade F. Dobler... successfully defended' the idea'. Collected Works, vol. 32, p. 132.

${ }^{36}$ Collected Works, vol. 19, p. 278.

${ }^{37}$ Collected Works, vol. 33, pp. 470, 464

${ }^{38}$ Collected Works, vol. 28, p. 451.

${ }^{39}$ Ibid.,p. 452.

${ }^{40}$ Ibid.

${ }^{41}$ Collected Works, vol. 43, pp. 250-51, 282, 471-72, 524; vol. 37, pp. 519, 522, 529; Lenin on Library Organisation, pp. 22, 28-31, 107-09.

${ }^{42}$ Lenin on Library Organisation, p. 57.

${ }^{43}$ Collected Works, vol. 42, pp. 123-24; Lenin on Library Organisation, pp. 56-59, 139-37, 144-46, 147-49.

${ }^{44}$ Collected Works, vol. 29, pp. 337-38; see also vol. 32, pp. 121-22, 126-32; vol. 35, p. 482.

${ }^{45}$ Lenin on Library Organisation, pp. 147-49; Collected Works, vol. 32, p. 127.

${ }^{46}$ Collected Works, vol. 32, p. 131. Lenin emphasised the importance of gathering every available book for public use. On the occasions where books were being destroyed, he intervened directly, as, for instance, in the following letter to G. Y. Zinoviev: 'Pokrovsky tells me that the library of the former Free Economic Society is being pilfered and books are even being burned. I 
emphatically request you to verify this, put a stop to the scandal, and let me have the name of the responsible local inspector'. See Collected Works, vol. 44, p. 349.

${ }^{47}$ Lenin on Library Organisation, p. 145.

${ }^{48}$ Ibid., 53.

${ }^{49}$ Ibid.

${ }^{50}$ Collected Works, vol. 44, p. 494

${ }^{51}$ Ibid., p. 177. Lenin did not want to ban the ex-owners of private libraries from accessing their collections after requisitioning them for the public. For instance, after approving the requisition of Surkov's library, he wrote another letter to Prokofiev, stating that 'I hope, nevertheless, [that] you will do everything possible to give Surkov some satisfaction: for example, the right to use it, and so forth'. See ibid., p. 180.

${ }^{52}$ Lenin on Library Organisation, p. 42.

${ }^{53}$ Collected Works, vol. 26, 352. 